GRASAS Y ACEITES 70 (3)

July-September 2019, e313

ISSN-L: 0017-3495

https://doi.org/10.3989/gya.0711182

\title{
Establishment of an aqueous method for extracting soybean oils assisted by adding free oil
}

\author{
J. Tu ${ }^{\mathrm{a}}$ and $\mathrm{W} . \mathrm{Wu}^{\mathrm{a}, \mathrm{b}, \mathbb{}}$ \\ ${ }^{a}$ College of Food Science, Southwest University, 216 Tian Shengqiao, Beibei, Chongqing, PRC. \\ ${ }^{\mathrm{b}}$ Academic Committee of the International Research Centre for Sustainable Built Environment of Chongqing University. \\ Corresponding author:wbwu62@yahoo.com
}

Submitted: 23 July 2018; Accepted: 12 November 2018. Published online: 30 April 2019

SUMMARY: Concern for the environment, safety and costs has promoted the development of the method for extracting soybean oil by an aqueous process. An advanced aqueous extraction of soybean oil assisted by adding free oil was established in this study, which recovered $81 \%$ of the oil from soybeans with $20.73 \%$ crude oil content and produced a de-oiled residue with $4.7 \%$ residual oil. The acid or peroxide value of the recovered oil met the Chinese national standard for first class refined oil, which was lower than that produced by solvent extraction or high temperature pressing. No wastewater was produced during the aqueous extraction of oil. The removal of the oil by the addition of oil and a small amount of water generated a residue (solids) containing all the protein, which represents $2 / 3$ of the revenue in the soybean process. The protein-rich residue can be further processed to produce a protein isolate with high purity (e.g. $>90 \%$ ) by using a higher amount of water. It can also be used as a nutritious ingredient or raw material for the production of many food products, among other applications.

KEYWORDS: Addition of free oil; Aqueous process; Edible oil; High oil yield; Soybean

RESUMEN: Establecimiento de un método acuoso para extraer aceites de soja con ayuda de la adición de aceite libre. La preocupación por el medio ambiente, la seguridad y el costo fomenta el desarrollo de la extracción de aceites de soja mediante un proceso acuoso. En este estudio se estableció una extracción acuosa avanzada de aceite de soja con la ayuda de la adición de aceite libre, que recuperó el 81\% de los aceites de las semillas de soja con un contenido de aceite crudo del $20,73 \%$ y produjo un residuo que contenía un aceite residual del $4,7 \%$. La acidez o el índice de peróxido del aceite recuperado cumplió con la norma nacional china para el aceite refinado de primera clase, que fue inferior al producido mediante la extracción con solvente o el prensado a alta temperatura. No se produjo agua residual durante la extracción acuosa de aceites. La eliminación del aceite mediante la adición de aceite y una pequeña cantidad de agua generó un residuo (sólidos) que contiene toda la proteína, lo que representa 2/3 de los ingresos en el proceso de soja. El residuo rico en proteínas puede procesarse aún más para producir proteínas aisladas con alta pureza (v.g. $>90 \%$ ) usando una mayor cantidad de agua. También se puede utilizar como ingrediente nutritivo o materia prima para la producción de muchos productos alimenticios, etc.

PALABRAS CLAVE: Aceite comestible; Adición de aceite libre; Alto rendimiento de aceite; Haba de soja; Proceso acuoso

ORCID ID: Wu W https://orcid.org/0000-0002-4000-5709, Tu J https://orcid.org/0000-0002-4191-3514

Citation/Cómo citar este artículo: Wu W, Tu J. 2019. Establishment of an aqueous method for extracting soybean oils assisted by adding free oil. Grasas Aceites 70 (3), e313. https://doi.org/10.3989/gya.0711182

Copyright: (C2019 CSIC. This is an open-access article distributed under the terms of the Creative Commons Attribution 4.0 International (CC BY 4.0) License. 


\section{INTRODUCTION}

The nutritional value of soybeans has been applauded by scientists in the literature because they provide high quality oil and proteins (Weingartner, 2008; Pare et al., 2014). Particularly, the prevention of the denaturation of proteins is inevitably taken into consideration when the extraction method of oil is developed or selected. Therefore, the extraction method of soybean oil is an important issue which attracts widespread attention.

The disadvantages of solvent extraction and high temperature pressing which are currently used for the commercial production of soybean oil throughout the world have been extensively reported (Tu et al., 2017; Zhang, 2016; Pare et al., 2014; Latif and Anwar, 2009; Lamsal et al., 2006; Johnson, 2000; Environmental Protection Agency, 1999). Therefore, the development of an aqueous extraction of oil from oil seeds including soybeans has been promoted (Pare et al., 2014; Moura et al., 2009; Lamsal et al., 2006; Rosenthal et al., 2001; Rosenthal et al., 1998; Yoon et al., 1991). All the aqueous extraction methods for soybean oil published in the literature use large quantities of water (i.e. liquid:solid ratio larger than 2:1), because the extraction yield of oil and proteins from soybeans is traditionally thought to be reduced by the use of a reduced amount of water (higher solids-toliquid ratio), and not the other way around. A low solids-to-liquid ratio of 1:10 was reported to favor both oil and protein extraction from soybeans, and resulted the extraction of $96 \%$ oil and $85 \%$ protein. The extracted oil was distributed as $21-23 \%$ in the free oil, $57-61 \%$ in the cream, and $14-17 \%$ in the skim while the un-extracted oil (accounted for 4\% of the total oil from soybeans) was in the insoluble fraction (Moura et al., 2009). The recovery of free oil from the cream requires the aid of enzymes (proteases) while $100 \%$ recovery is still difficult. The recovery of oil from the skim (the protein-rich aqueous phase) is very difficult, which renders the difficulty of producing a protein isolate with $90 \%$ purity. Particularly, the large volume of the aqueous phase produced requires further processing, which is very costly. In addition, the insoluble fraction (solid fraction after centrifugation) needs to be dried, which is also costly. Therefore, the methods which use large quantities of water have three disadvantages: low final recovery yield of oil due to emulsion formed during extraction or even no free oil produced; large quantities of waste water produced; high cost of drying the de-oiled insoluble fraction or the aqueous phase (Li et al., 2016; Ravber et al., 2015; Zhang et al., 2011; Jiang, 2010; Hanmoungjai et al., 2000; Rosenthal et al., 1996).

The aim of this study was to develop a new aqueous procedure for extracting soybean oil by adding free oil since the current recovery yield achieved by the aqueous extraction process reported in the literature appears to be $<80 \%$. This new aqueous method for extracting soybean oil is based on the aggregation of hydrophilic groups of compounds with and without hydrophobic groups via hydrogen bonds with the prevention of their solubilization or dispersion by adding the proper (small) amount of water as a prerequisite. This method is different from the aqueous method reported in the literature which relies on the complete dispersion of the compounds without hydrophobic and hydrophilic groups by using large quantities of water.

\section{MATERIALS AND METHODS}

\subsection{Materials}

Soybeans were obtained from the Chengdu People Nutritious Food Factory, China. Their moisture content was $10.35 \pm 0.11 \%$. The oil content on the dry basis of baked and peeled soybeans was $20.73 \pm 0.20 \%$. Soybean oil (first-class refined oil according to Chinese national standard) was obtained from the Arowana Business, China.

\subsection{Establishment of critical operating conditions and optimization}

\subsubsection{Section 1. Effect of the amount of water added on oil yield}

The soybeans were baked at $120{ }^{\circ} \mathrm{C}$ for $5 \mathrm{~min}$. Then the baked soybeans were cooled and peeled. The peeled soybeans were rolled into slices and then extruded via a cold spiral press (made by Ai Bang Agricultural and Horticultural Machinery Plant, China) at $20^{\circ} \mathrm{C}$. Soybean oil ( 3 parts) was mixed with the rolled and extruded soybeans (5 parts). After mixing well, the mixture was ground by hand and passed through a 100 mesh sieve. These procedures prepared the slurry (mixture of soybeans and refined soybean oil added (SSO)). Every $10.00 \mathrm{~g}$ SSO was weighed into a container and mixed with sodium chloride $(0.1000 \mathrm{~g})$. Then, $0.00,1.00,1.10$, $1.20,1.25,1.30,1.35,1.40$, or $1.50 \mathrm{~mL}$ of water were added into a container. The mixtures were agitated at $65^{\circ} \mathrm{C}$ for $10 \mathrm{~min}$. After agitation, the mixture of free oil and aggregated hydrophilic group was transferred into a $20 \mathrm{~mL}$ centrifuge tube and centrifuged at $4000 \mathrm{r} / \mathrm{min}$ for $30 \mathrm{~min}$. This step was repeated three times. Finally, the residue at the bottom of the centrifuge tube was pressed by cold pressing at room temperature via a spiral cold press (made by Ai Bang Agricultural and Horticultural Machinery Plant, China). Three replicates of each sample were performed. The oil content in the de-oiled and dried residue from the spiral cold press was determined. The oil yield (OY) was calculated using the following formula: 


$$
\mathrm{OY}(\%)=\frac{\text { Soc } \times \text { WBPSS }- \text { Roc } \times \text { WTDDR }}{\text { Soc } \times \text { WBPSS }} \times 100
$$

where $\mathrm{S}_{\mathrm{oc}}, \mathrm{R}_{\mathrm{oc}}$, WBPSS and WTDDR represent the oil fraction of the original baked and peeled soybean sample (dry basis), the oil fraction of the de-oiled residue which was dried after pressing by the spiral cold press, the weight $(\mathrm{g})$ of the baked and peeled soybean sample and the weight $(\mathrm{g})$ of the total dry de-oiled residue, respectively.

\subsubsection{Section 2. Effect of baking temperature on oil yield}

The soybeans were baked at $100{ }^{\circ} \mathrm{C}, 110{ }^{\circ} \mathrm{C}$, $120^{\circ} \mathrm{C}, 130^{\circ} \mathrm{C}$, or $140^{\circ} \mathrm{C}$ for 0 or $5 \mathrm{~min}$. The procedure for preparing SSO, the separation of oil and the method for determining OY were the same as that described in 2.2.1. The difference was that the amount of water added was fixed at $1.4 \mathrm{~mL}$.

\subsubsection{Section 3. Effect of amount of sodium chloride added on oil yield}

The soybeans were baked at $120{ }^{\circ} \mathrm{C}$ for $5 \mathrm{~min}$. The rest procedure of preparing SSO, the separation of oil and the method of determining OY were the same as that described in 2.2.1. Every $10.00 \mathrm{~g} \mathrm{SSO}$ was weighed and mixed with water $(1.30 \mathrm{~mL})$. Then, sodium chloride $(0,0.0200,0.0400,0.0600,0.0800$, 0.1000 , or $0.1200 \mathrm{~g}$ ) was added into a container. The mixtures were agitated at $65^{\circ} \mathrm{C}$ for $10 \mathrm{~min}$.

\subsubsection{Section 4. Effect of temperature or time of agitation on oil yield}

The soybeans were baked at $120{ }^{\circ} \mathrm{C}$ for $5 \mathrm{~min}$. The procedure for preparing SSO, the separation of the oil and the method for determining OY were the same as that described in 2.2.1. Every $10.00 \mathrm{~g} \mathrm{SSO}$ were weighed and mixed with water $(1.30 \mathrm{~mL})$ and sodium chloride $(0.0800 \mathrm{~g})$. Series of mixtures were agitated at $20,30,40,50,60,65,70,75,80$, or $85^{\circ} \mathrm{C}$ for $10 \mathrm{~min}$ to test the effect of agitation temperature on OY. In addition, another series of the mixtures were agitated at $75^{\circ} \mathrm{C}$ for $10 \mathrm{~min}, 20 \mathrm{~min}, 30 \mathrm{~min}$, or $40 \mathrm{~min}$, respectively, to test the effect of agitation time on OY.

\subsubsection{Section 5. Effect of milling time on oil yield}

The soybeans were baked at $120^{\circ} \mathrm{C}$ for $5 \mathrm{~min}$. The procedure of preparing SSO, the separation of the oil and the method for determining OY were the same as that described in 2.2.1. Then, a series of SSO were transferred to a mortar and milled for $0 \mathrm{~h}, 0.5 \mathrm{~h}, 1.0 \mathrm{~h}, 1.5 \mathrm{~h}, 2.0 \mathrm{~h}$, or 2.5 . Every milled SSO $(10.00 \mathrm{~g})$ was weighed and mixed with water
$(1.30 \mathrm{~mL})$ and sodium chloride $(0.0800 \mathrm{~g})$. The mixtures were agitated at $75^{\circ} \mathrm{C}$ for $30 \mathrm{~min}$.

\subsubsection{Section 6. Effect of the addition of refined oil on the yield of soybean oil}

The procedure was the same as that described in "2.4". The only difference was that the refined oil was not added in this experiment. The OY was measured by the same method as that described in 2.2.1.

\subsection{Comparison of oil yield obtained by different separation methods}

The procedure was the same as that described in "2.4". The only difference was that after agitation the mixture of free oil and aggregated hydrophilic group (a large rigid particle formed because of hydrogen bonds) was separated by the following methods: A (Centrifuging three times), B (Centrifuging + cold spiral pressing) and $\mathrm{C}$ (Cold spiral pressing three times). The OY was measured by the same method as that described in 2.2.1.

\subsection{The procedure finally established for the extraction of soybean oil by aqueous solution}

The soybeans were baked at $120{ }^{\circ} \mathrm{C}$ for $5 \mathrm{~min}$. The procedure for preparing $\mathrm{SSO}$ was the same as that described in 2.2.1. The SSO was transferred to a mortar and milled for $2.5 \mathrm{~h}$. Every milled SSO $(10.00 \mathrm{~g})$ was weighed and mixed with water $(1.30 \mathrm{~mL})$ and sodium chloride $(0.0800 \mathrm{~g})$. The mixture was agitated at $75^{\circ} \mathrm{C}$ for $30 \mathrm{~min}$. After agitation, the mixture of free oil and the aggregated hydrophilic group was pressed three times by cold pressing at room temperature via a spiral cold press (made by Ai Bang Agricultural and Horticultural Machinery Plant, China).

\subsection{Other methods of determination}

Crude fat was measured according to Chinese national standards GB 5009.6-2016. Moisture content was measured according to Chinese national standards GB 5009.3-2016. Acid value and peroxide value were determined according to Chinese national standards GB 5009.229-2016 and GB 5009.227-2016, respectively. All experiments were carried out in triplicate, and the mean and standard errors were calculated and reported for each determination.

\subsection{Statistical analysis}

The means of the data were analyzed by One-way ANOVA using IBM SPSS Statistics. The level of significance was set at $\mathrm{P}<0.05$. 


\section{RESULTS}

\subsection{Establishment of critical operating conditions and their optimization}

\subsubsection{Section 1. Effect of the amount of water added on oil yield}

The results indicated that no oil from the soybean sample was extracted and $52.43 \%$ of the refined oil added was absorbed instead when no water was added. The effect of the amount of water added on the $\mathrm{OY}$ is indicated in Figure 1. From this figure, it can be seen that the OY dramatically increased when the amount of water added was increased from 1.00 to $1.30 \mathrm{~mL}$. However, the OY gradually decreased when the amount of water added was further increased from 1.4 to $1.5 \mathrm{~mL}$. Among all the amounts of water investigated, $1.30 \mathrm{~mL}$ gave the highest OY. The highest OY obtained in this experiment was $67.74 \pm 0.58 \%$, which should indicate that some other operating conditions also affected the aqueous extraction of soybean oil.

The results mentioned above mean that the addition of water is essential for the extraction of soybean oil. The addition of water should be necessary for the formation of hydrogen bonds among the hydrophilic compounds such as proteins, saccharides, phospholipids, and free fatty acids for them to aggregate together into a large rigid and sticky particle. This may also enhance the hydrophobic interaction between oil molecules. These reactions caused the release of oil from the aggregated hydrophilic particle. However, the addition of an excessive amount of water was harmful to the extraction of soybean oil. The reason for this may be that some hydrophilic compounds such as free fatty acids, phospholipids and phenolic compounds dissolved

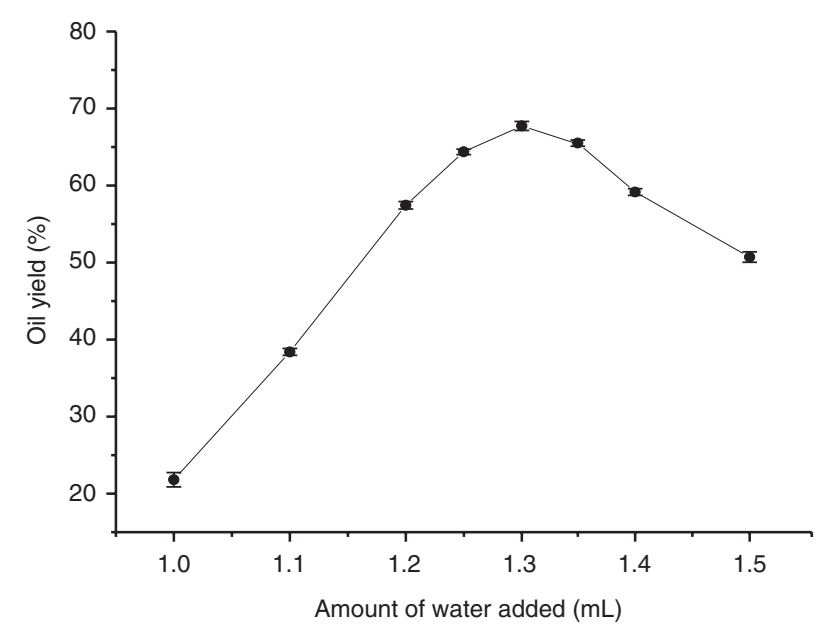

FIGURE 1. Effect of amount of water added on the final yield of soybean oil. in the water so that emulsification was enhanced and OY was reduced.

\subsubsection{Section 2. Effect of baking temperature on oil yield}

The results from this experiment showed that the OY $(56.18 \pm 0.74 \%)$ obtained without baking was not significantly different from that $(56.79$ $\pm 0.87 \%$ ) obtained at $100{ }^{\circ} \mathrm{C}$ baking temperature $(\mathrm{P}>0.05)$. The effect of baking temperatures from 100 to $130{ }^{\circ} \mathrm{C}$ is shown in Figure 2. The OY gradually increased when the baking temperature was increased from 100 to $120{ }^{\circ} \mathrm{C}$. However, the OY dramatically decreased when the baking temperature was further increased to $130{ }^{\circ} \mathrm{C}$. The difference in the $\mathrm{OY}$ at baking temperatures between $110^{\circ} \mathrm{C}$ $(58.23 \pm 0.58 \%)$ and $120{ }^{\circ} \mathrm{C}(58.64 \pm 0.65 \%)$ was not significant $(\mathrm{P}>0.05)$. The lower $\mathrm{OY}$ than that described in 3.1.1., should be caused by a higher amount of water used in this trial. The reason for this was that the experiment described here was carried out before the experiment described in 3.1.1., which established the optimum amount of water added for obtaining optimum OY.

The results mentioned above should indicate that baking at an appropriate temperature improved the efficiency of extracting soybean oil by using an aqueous solution though increased by only $2 \%$ in the OY. The reason for obtaining this effect may be that baking can deactivate lipase in soybeans and a baking temperature which is too high may denature storage proteins, which increases their oil-binding capacity and therefore decreases the OY. The deactivation of lipase can reduce the hydrolysis of neutral oil which facilitates emulsification and reduces OY during aqueous extraction. In fact, whole oil seeds can lose neutral oil during storage if their storage

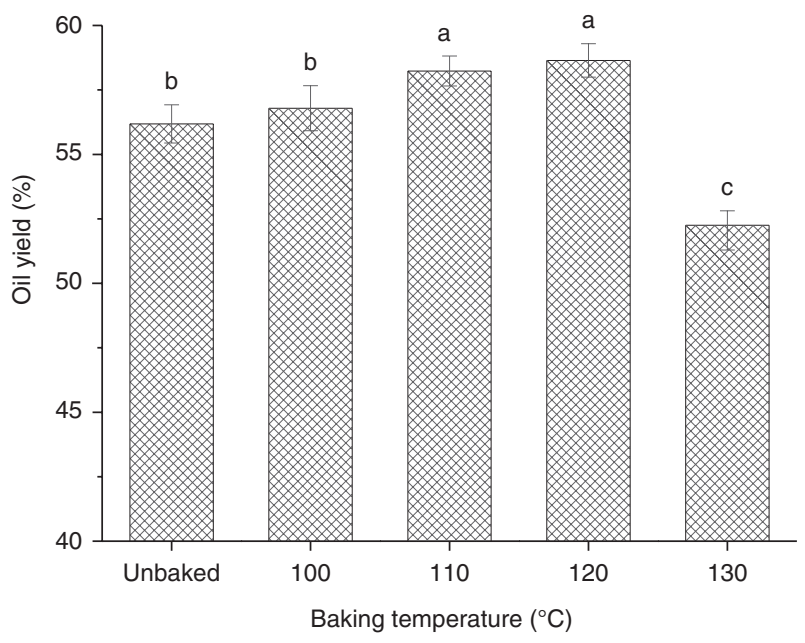

FIGURE 2. Effect of baking temperature on the final yield of soybean oil. 
temperature and moisture content are high enough. Therefore, it is reasonable to believe that the loss of neutral oil in the soybean seed slurry with the addition of water and agitation is very likely if lipase is not deactivated. Another advantage of baking is that the flavor of the oil recovered can be improved.

\subsubsection{Section 3. Effect of amount of sodium chloride added on yield of oil}

The results from this experiment are shown in Figure 3. It is obvious that OY increased gradually from $59.47 \pm 0.51$ to $67.62 \pm 0.32 \%$ when the amount of sodium chloride was increased from 0.00 to $0.08 \mathrm{~g}$. The difference in the OY was not significant, although it was slightly decreased when the amount of sodium chloride was increased from 0.08 to $0.12 \mathrm{~g}$.

Therefore, the addition of sodium chloride greatly increased the efficiency of extracting soybean oil using an aqueous solution. The increment in OY resulting from the addition of sodium chloride was $>8 \%$. This means that the addition of sodium chloride is critical for achieving high OY. The addition of salt to the water can result in changes in the surface tension and surface charge of the protein or carbohydrate, which increases the polarity of the hydrophilic group. This effect can increase the non-covalent interaction of the polymer with water by the action of ionic bonds, which then extrude the oil from the aggregated polymer. The addition of salt can also increase the water density and therefore increase the density difference between the aqueous sediment and the supernatant oil. However, the soybean OY dramatically decreased when the amount of salt further increased to higher than $0.08 \mathrm{~g}$, which may be caused by a decrease in the availability of water.

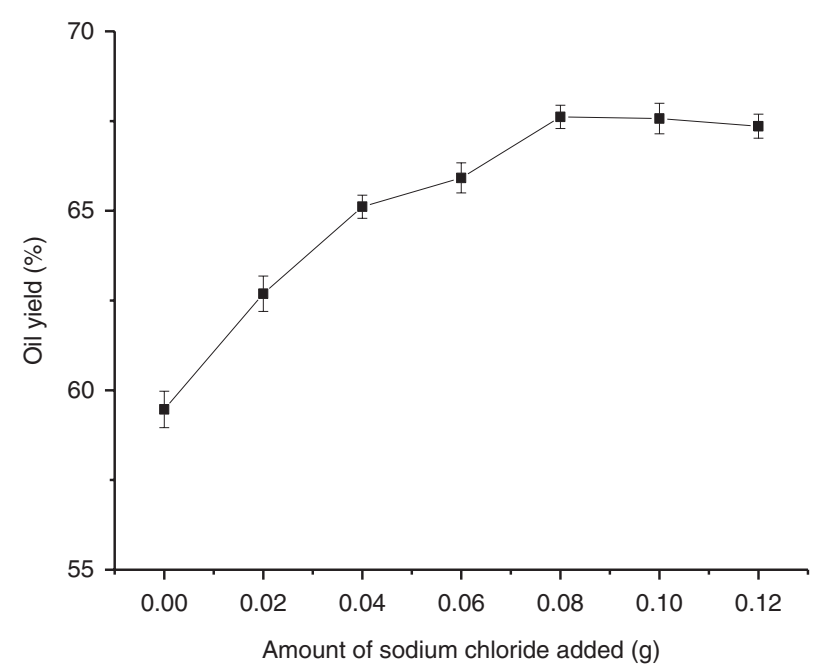

FIGURE 3. Effect of amount of sodium chloride added on the final yield of soybean oil.

\subsubsection{Section 4. Effect of temperature and time of agitation on oil yield}

Figure 4 shows that the OY gradually increased from $56.01 \pm 0.89$ to $73.28 \pm 0.58 \%$ when the agitation temperature was increased from $20^{\circ} \mathrm{C}$ to $75^{\circ} \mathrm{C}$. However, the OY was decreased significantly when the agitation temperature further increased to 80 or $85^{\circ} \mathrm{C}$. The decrement in OY was $>1 \%$. The OY was slightly decreased, but the difference was not significant when the agitation temperature increased from 80 to $85^{\circ} \mathrm{C}$. This figure also shows that agitation time greatly affected OY. The result showed that the OY decreased from $73.28 \pm 0.58$ to $71.50 \pm 0.35 \%$ when the agitation time decreased from $10 \mathrm{~min}$ to $5 \mathrm{~min}$. The OY gradually increased to $75.27 \pm 0.35 \%$ when the agitation time was increased from 5 min to $30 \mathrm{~min}$. Although the OY slightly increased, the difference was not significant when the agitation time further increased to $40 \mathrm{~min}$.

Therefore, the agitation temperature greatly increased the efficiency of extracting soybean oil using an aqueous solution. The increment in the OY resulting from the appropriate increase in agitation temperature was $>17 \%$. This means that the appropriate agitation temperature is critical for achieving high OY. Furthermore, the increment in OY resulting from the increase in agitation time was ca. $2 \%$ when other operating conditions were fixed. For achieving high OY, this factor should not be ignored.

\subsubsection{Section 5. Effect of milling time on oil yield}

From Figure 5 it can be seen that the OY gradually increased to $80.49 \pm 0.18 \%$ when the milling time increased from 0 to $2.5 \mathrm{~h}$. The OY was 75.01

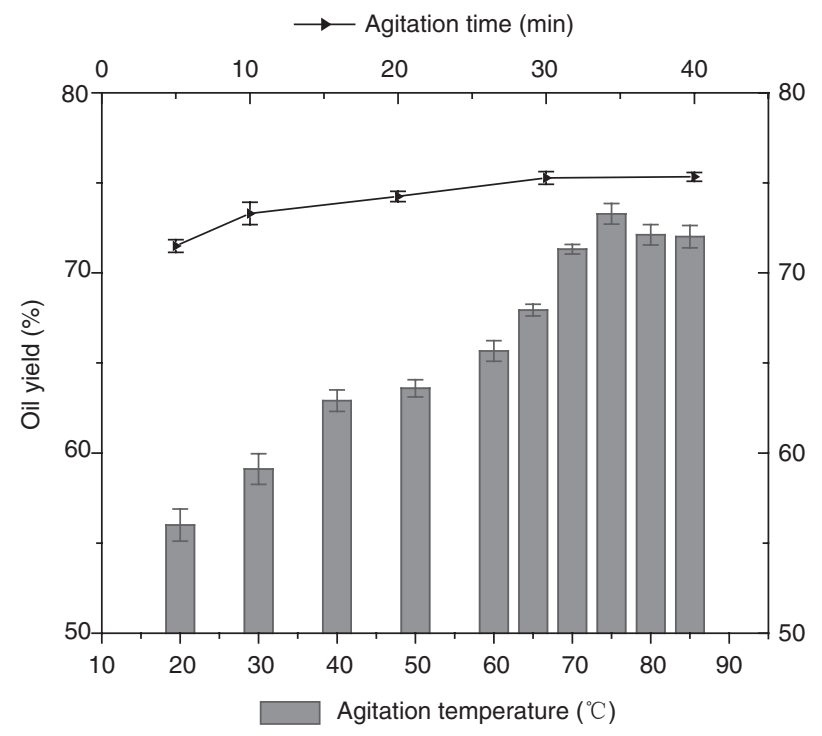

FIGURE 4. Effect of agitation temperature and time on the final yield of soybean oil. 


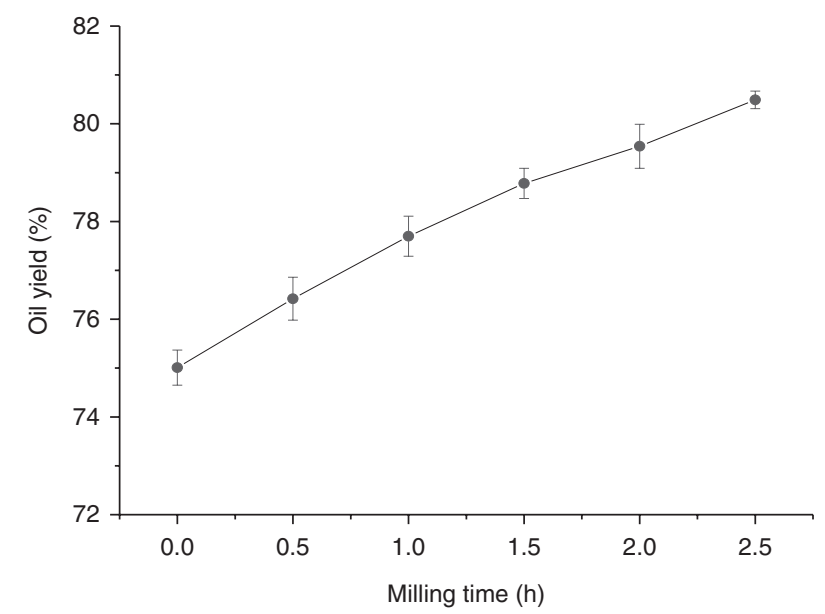

FIgURE 5. Effect of milling time on the final yield of soybean oil.

$\pm 0.36 \%$ when the soybeans were rolled, extruded and ground through a 100 mesh sieve (having $154 \mathrm{~mm}$ pore size) without a further milling process (i.e. milling for $0 \mathrm{~h}$ ). The increment in OY resulting from the milling process was $>5 \%$. From this figure, it can also be seen that no maximum OY was obtained. This may mean that a further increase in milling time would be able to further elevate the OY. In this experiment, the milling process was carried out by hand, which may not be as efficient as a milling machine. Therefore, a sufficient milling process should be critical for crushing all oil bodies to release all oil in soybeans so that high OY can be achieved. Since the size of oil bodies in soybeans ranging from 0.72 to $14 \mathrm{~mm}$ was reported (Lardizabal et al., 2008) and we found that it was difficult to grind soybean slurry through a 500-mesh sieve (having $30.8 \mu \mathrm{m}$ pore size), a sufficient seamless milling process should further increase the OY significantly.

\subsubsection{Section 6. Effect of the addition of refined oil on soybean oil yield}

The results from this experiment indicated that the OY was only $4.76 \pm 0.31 \%$ (Figure 6) and the oil content in the de-oiled residue was $19.94 \pm 0.04 \%$ when no refined oil was added and all other operating conditions were fixed to the point which gave the maximum $\mathrm{OY}$ found in all the experiments described in the above sections. This result means that the addition of refined oil is essential and critical for the extraction of oil (which was only $20.73 \pm$ $0.20 \%$ in soybeans) by aqueous solution. This result may apply to any other oil seeds which are similar to soybeans and have low oil contents. The addition of free oil should enhance the hydrophobic interaction between oil molecules. This can also promote the aggregation of hydrophilic compounds by hydrogen bonds because of the addition of water

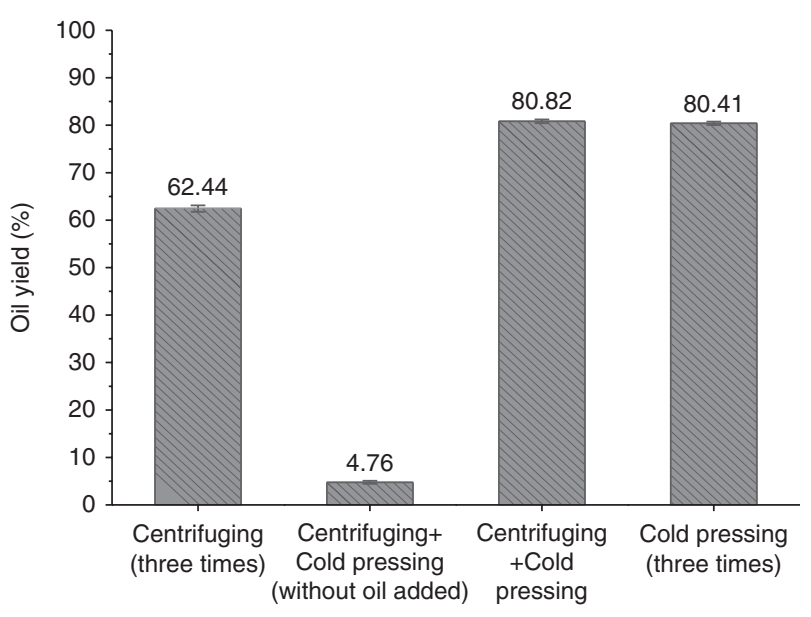

FIGURE 6. Comparison of the final yield of soybean oil by different separating methods.

and facilitate the release of free oil from the aggregated hydrophilic particle.

\subsection{Comparison of oil yield obtained by different separation methods}

According to the experiments described in 3.1, the critical operating conditions or parameters from the step of agitation upstream were established and optimized. Then the efficiency of different methods for separating free oil and aggregated hydrophilic group (solid) were compared when the established and optimized operating conditions or parameters were employed.

This study found that A (centrifuging three times), B (centrifuging + cold spiral pressing) and C (cold spiral pressing three times) produced a de-oiled residue containing $8.94 \pm 0.15 \%, 4.78 \pm 0.09 \%$ and $4.88 \pm 0.09 \%$ residual oil (dry basis), respectively. The OY corresponding to this residual oil is shown in Figure 6. The OY from methods $\mathrm{B}$ and $\mathrm{C}$ was not significantly different $(\mathrm{P}>0.05)$. Therefore, the method $\mathrm{C}$ was good enough for efficiently separating free oil and aggregated hydrophilic group (solid).

\subsection{The procedure finally established for the extraction of soybean oil by aqueous solution}

According to the experimental results described in 3.1 and 3.2, a feasible procedure for efficiently extracting oil from soybeans was established, and described in 2.4. The process flow diagram of this procedure is shown in Figure 7. All the conditions that gave the maximum OY were selected. The plotted results of the effect of agitation time on OY gave an asymptote so that $30 \mathrm{~min}$ was selected rather than 40 min because of the reduction in operating cost and time. The experiment on the effect of milling time obtained the result of a continuous increase 


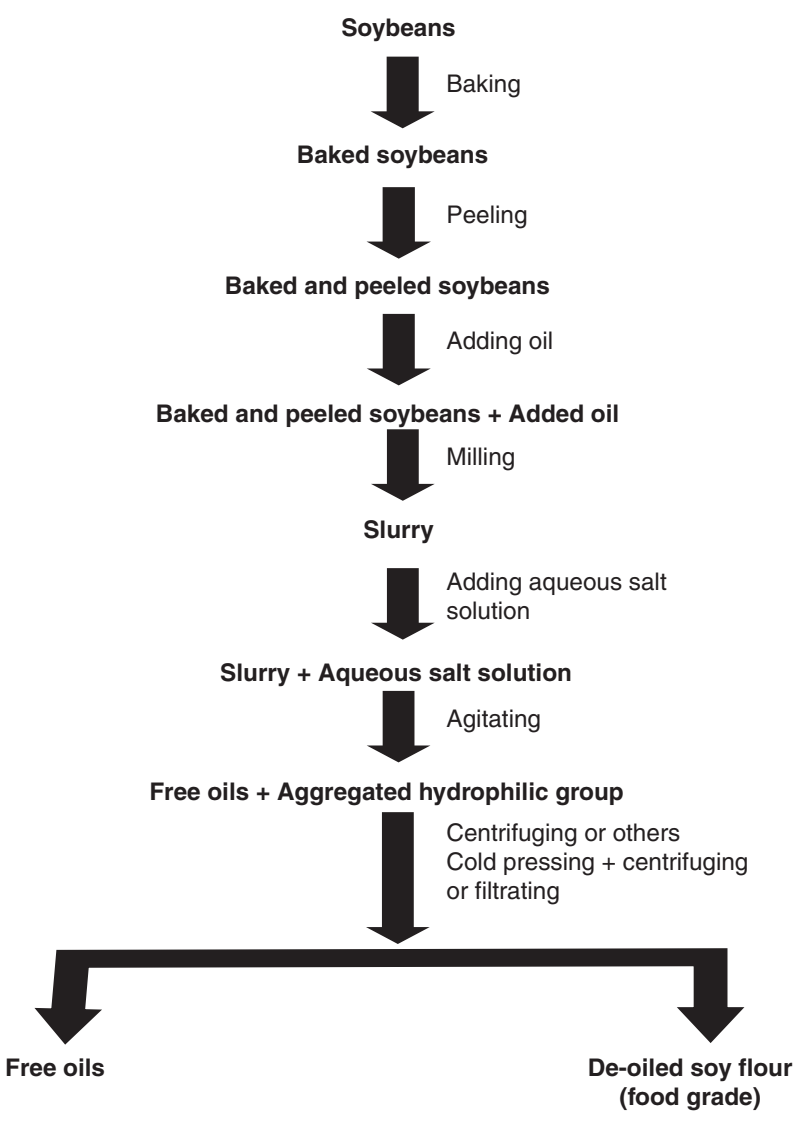

FIGURE 7. Process flow diagram of producing soybean oil by aqueous extraction assisted by the addition of free oil.

in OY till $2.5 \mathrm{~h}$ (the longest milling time tested). Therefore, it is temporarily proposed to select a milling time of $2.5 \mathrm{~h}$. This does not rule out a longer milling time selected in the future by further experimentation. Further extension of milling time or improvement in efficiency of milling may reduce the residual oil content in the de-oiled residue to a level lower than 4 or even $3 \%$.

The result of our final test on this procedure for producing soybean oil indicated that the OY was $81.00 \%(4.70 \%$ residual oil content in the deoiled residue on dry basis). The OY obtained by using the method developed in this study was much higher than that $(73 \%)$ obtained by ohmic heating and the enzyme assisted aqueous extraction method (Pare et al., 2014). The extraction yield by flaking and extrusion pre-treatment followed by enzymeassisted aqueous extraction method was reported to be $88 \%$ using soybeans containing $23.8 \%$ oil as a studying material, but the recovery yield of oil was not stated (Lamsal et al., 2006). However, the majority of oil extracted was in emulsion so that the final recovery yield of free oil should be much lower than this reported extraction yield. If the method developed in this study is used to process soybeans containing $23.8 \%$ oil, the OY can reach to ca. $85 \%$.
The oil produced by the method developed in this study had an acid value of $0.19(\mathrm{mg} \mathrm{KOH} / \mathrm{g})$ and 4.81 peroxide value $(\mathrm{mmol} / \mathrm{kg})$ which met the Chinese standard for first-class refined oil. This method produced oils with higher quality as compared to solvent extraction and high temperature pressing.

In this study, the removal of oil by the addition of oil and a small amount of water generated a residue (solids) containing all the protein, which represents $2 / 3$ of the revenue in the soybean process. The protein-rich residue can be further processed to produce protein isolate with high purity (e.g. $>90 \%$ ) by using a higher amount of water. It can also be directly used as a nutritious ingredient or raw material for the production of many food products, among other applications.

\section{DISCUSSION}

The aqueous method of extracting oil from soybeans assisted by adding free oil which was developed in this study produced high OY $(81.00 \%)$. The reason for the efficiency of this method using a small amount of water rather than using the large quantities of water reported in the literature should be that these two methods have different mechanisms. The method developed in this study added the proper amount of water with its quantity (liquid:material ratio $<1: 5$ ) enough to result in interactions (mainly via hydrogen bonds) between hydrophilic groups of compounds which may also contain hydrophobic groups (e.g. phospholipids, proteins, amino acids, saponins), but not enough to solubilize or disperse any of them as a prerequisite. The aggregation of hydrophilic compounds into a large and rigid particle repels oil so that a free oil phase is obtained. The addition of free oil enhanced this kind of reaction. On the other hand, the traditional method using large quantities of water (liquid:material ratio $>2: 1$ ) primarily relies on the full solubilization or complete dispersion of compounds having both hydrophilic and hydrophobic groups (e.g. phospholipids, proteins, amino acids, saponins) which facilitate the formation of stable emulsion with oil (Campbell and Glatz, 2009). Therefore, the final OY of free oil obtained by the traditional aqueous method is usually quite low though the extraction yield of oil can be very high because of stable emulsion.

The reasonably low water content in the defatted meal with high quality, no wastewater generated during the extraction of oil, the high OY and good quality of oil recovered should show that the aqueous method developed in this study is superior to traditional or enzyme-assisted aqueous method which uses large quantities of water, solvent extraction and traditional high temperature expressing.

With regard to the comprehensive utilization of soybeans, the new aqueous method developed in this 
study is comparable to solvent extraction and superior to the enzyme-assisted aqueous method and pressing at high temperature. The aqueous method developed in this study is comparable to pressing at high temperatures and superior to solvent extraction and enzyme-assisted aqueous method in terms of reducing equipment investment. The method developed in this study is superior to solvent extraction, enzyme-assisted aqueous method and pressing at high temperatures in terms of reducing production cost. Furthermore, the method developed in this study is superior to solvent extraction and enzymeassisted aqueous method for the purpose of decreasing adverse effects on the environment.

The experimental method described in this paper established operational variables to obtain $81 \%$ oil recovery rate which was better than other methods such as hot-pressing alone or cold-pressing alone, or traditional aqueous method using large quantities of water including those enzyme-assisted, except for solvent extraction. Therefore, the methods used in this study were adequate, and resulted in that the aim of the work was clearly established. Further optimization such as surface response experimentation may be a valuable attempt to further improve the oil recovery rate. However, it may be better left for future study since the operational variables were good to obtain a meaningful oil recovery rate from the point view of commercial processing of soybeans.

In 2.2.1., we clearly indicated that the mixture of soybeans and refined soybean oil added (SSO) was prepared by grinding 3 parts refined soybean oil with 5 parts rolled and extruded soybeans to pass through a 100 mesh sieve by hand. All experiments were performed by using SSO as a study material. In 3.1.1., it has been clearly described that no oil from SSO was extracted and $52.43 \%$ of the refined oil added was absorbed instead when no water was added (by centrifuging three times followed by pressing or by hotpressing alone or by cold-pressing alone). When the proper amount of $6.1 \%$ aqueous salt solution was added to SSO followed by proper agitation, free oils were released and the solids aggregated into a sticky and large particle. The majority of the oil released can be directly poured out of the agitator container. Only minor oil needs to be collected by pressing or centrifuging. If the oil is collected by pressing alone, it may contain a tiny amount of solids which must be removed by centrifugation. If the soybean was directly treated by hot pressing alone, the recovery rate of oil was less than $70 \%$ while cold pressing alone had a much lower recovery rate of oil. In 3.1.6., it has been clearly indicated that only $4.76 \%$ oil was recovered when no refined oil was added. Therefore, the addition of water and refined oil is essential for the extraction of oil from soybeans. Others are auxiliary measures.

Because the purpose of this study was to establish a new aqueous method for the extraction of oil from soybeans, de-oiled meal was just a by-product and its properties were not analyzed in details. However, since soybean is a kind of edible seed, the de-oiled meal should be applicable in the food industry.

Baking was an efficient method for deactivating lipase and therefore preventing the loss of neutral oil during extraction and decreasing the acid value of the oil produced, which should be applied to any kind of aqueous method. It should be noted that dry-heating is not likely to reduce the solubility of protein and may cause an adverse effect on oil quality.

The extraction of oil by this method at such a low temperature should produce oil with a quality similar to or even better than that obtained by cold-pressing. Such surfactants as phospholipids, free fatty acids, and amino acids should remain in the aggregated hydrophilic particle, which was the reason that the oil produced by this new aqueous method was clean and had high quality.

\section{CONCLUSIONS}

Aqueous extraction assisted by adding free oil was very efficient and had the potential of being a classic procedure for processing soybeans in the future and forever. The addition of an appropriate amount of both free oil and water was found to be essential and critical for extracting oil from soybeans. The amount of water and sodium chloride added must be appropriate since an excess of them was found to be harmful to the recovery of free soybean oil. The temperature for baking soybeans and agitating the soybean slurry containing free oil added was also found to be critical for achieving high OY, but it must be appropriate since a temperature which was too high was harmful to the recovery of free soybean oil. The extension of milling time of the soybean slurry containing added free oil positively correlated with OY. No wastewater was produced by using the aqueous extraction method developed in this study. The method developed in this study also produced high quality de-oiled residue which can be directly used in the food industry or further processed to produce protein isolate with high purity (e.g. $>90 \%$ ) by using a higher amount of water. This method may be applied to the processing of any oil seed similar to soybeans which have a low oil content.

\section{REFERENCES}

Campbell K, Glatz CE. 2009. Mechanisms of Aqueous Extraction of Soybean Oil. J. Agric. Food Chem. 57, 10904-10912. https://doi.org/10.1021/jf902298a

Environmental Protection Agency. 1999. Integrated Risk Information System (IRIS) on n-Hexane. National Center for Environmental Assessment, Office of Research and Development, Washington DC.

Hanmoungjai P, Pyle L, Niranjan K. 2000. Extraction of rice bran oil using aqueous media. J. Chem. Technol. Biotechnol. 75, 
348-352. https://doi.org/10.1002/(SICI)1097-4660(200005) 75:5<348::AID-JCTB233>3.0.CO;2-P

Jiang L. 2010. Pilot-scale process of aqueous enzymatic extraction of peanut oil and protein hydrolysates and study on peanut ACE inhibitory peptides. Jiangnan University, Wuxi.

Johnson LA. 2000. Recovery of Fats and Oils from Plant and Animal Sources, in Wan PJ and Farr W (Ed.) Introduction to Fats and Oils. AOCS Press, Champaign, IL. pp. 108-135.

Lamsal BP, Murphy PA, Johnson LA. 2006. Flaking and Extrusion as Mechanical Treatments for EnzymeAssisted Aqueous Extraction of Oil from Soybeans. J. Am. Oil Chem. Soc. 83, 973-979. https://doi.org/10.1007/ s11746-006-5055-5

Lardizabal K, Effertz R, Levering C, Mai J, Pedroso MC, Jury T, Aasen E, Gruys K, Bennett K. 2008. Expression of Umbelopsis ramanniana DGAT2A in Seed Increases Oil in Soybean. Plant Physiol. 148, 89-96. https://doi.org/10.1104/ pp. 108.123042

Latif S, Anwar F. 2009. Effect of aqueous enzymatic processes on sunflower oil quality. J. Am. Oil Chem. Soc. 86, 393-400. https://doi.org/10.1007/s11746-009-1357-8

Li P, Gasmalla MAA, Liu J, Zhang W, Yang R, Aboagarib EAA. 2016. Characterization and demusification of cream emulsion from aqueous extraction of peanut. J. Food Engin. 185, 62-71. https://doi.org/10.1016/j.jfoodeng.2016.04.003

Moura JMLN De, Almeida NM De, Johnson LA. 2009. Scale-up of enzyme-assisted aqueous extraction processing of soybeans. J. Am. Oil Chem. Soc. 86, 809-815. https:// doi.org/10.1007/s11746-009-1406-3

Pare A, Nema A, Singh VK, Mandhyan BL. 2014. Combined effect of ohmic heating and enzyme assisted aqueous extraction process on soy oil recovery. J. Food Sci. Technol. 51, 1606-1611. https://doi.org/10.1007/s13197-012-0685-0
Ravber M, Knez Ž, Škerget M. 2015. Simultaneous extraction of oil-and water-soluble phase from sunflower seeds with subcritical water. Food Chem. 166, 316-323. https://doi. org/10.1016/j.foodchem.2014.06.025

Rosenthal A, Pyle DL, Niranjan K. 1996. Aqueous and enzymatic processes for edible oil extraction. Enzym. Microb. Technol. 19, 402-420. https://doi.org/10.1016/S0141-0229(96)80004-F

Rosenthal A, Pyle DL, Niranjan K. 1998. Simultaneous Aqueous Extraction of Oil and Protein from Soybean: Mechanisms for Process Design. Transact. Instit. Chem. Engin. Part C 76, 224-230.

Rosenthal A, Pyle DL, Niranjan K, Gilmour S, Trinca L. 2001. Combined effect of operational variables and enzyme activity on aqueous enzymatic extraction of oil and protein from soybean. Enzym. Microb. Technol. 28, 499-509. https://doi.org/10.1016/S0141-0229(00)00351-3

Tu J, Wu W, Yang J, Li J, Ma X. 2017. A method of producing edible oils with high quality by water. J. Food Proc. Preserv. 41, e13280. https://doi.org/10.1111/jfpp.13280

Weingartner KE. 2008. Soybean processing. Souvenir, International Soybean Processing and Utilization Conference-V. CIAE Bhopal: I-30.

Yoon SH, Kim IH, Kim SH, Kwon TW. 1991. Effects of Enzyme Treatments and Ultrasonification on Extraction Yields of Lipids and Protein from Soybean by Aqueous Process. Korean J. Food Sci. Technol. 23, 673-676.

Zhang W. 2016. Aqueous extraction and nutraceuticals content of oil using industrial enzymes from microwave puffingpretreated Camellia oleifera seed powder. Food Sci. Technol. Res. 222, 31-38. https://doi.org/10.3136/fstr.22.31

Zhang SB, Lu QY, Yang H, Li Y, Wang S. 2011. Aqueous enzymatic extraction of oil and protein hydrolysates from roasted peanut seeds. J. Am. Oil Chem. Soc. 88, 727-732. https://doi.org/10.1007/s11746-010-1711-x 